\title{
Isolation and Identification of Emestrin from Emericella nidulans and Investigation of Its Anticancer Properties
}

\author{
MUHAMMAD NURSID ${ }^{1 *}$, EKOWATI CHASANAH ${ }^{1}$, MURWANTOKO $^{2}$, \\ AND SUBAGUS WAHYUONO ${ }^{3}$ \\ ${ }^{I}$ Research Center for Marine and Fisheries Product Processing and Biotechnology, \\ Kementerian Kelautan dan Perikanan, Jalan KS Tubun Petamburan VI, Jakarta 10260, Indonesia; \\ ${ }^{2}$ Fisheries Department, Faculty of Agriculture, Universitas Gadjah Mada, \\ Bulak Sumur, Yogyakarta 55281, Indonesia; \\ ${ }^{3}$ Faculty of Pharmacy,Universitas Gadjah Mada, \\ Sekip Utara, Yogyakarta 55281, Indonesia
}

\begin{abstract}
The research to isolate, identify and investigate of anticancer properties of active compound produced by Emericella nidulans marine fungus has been done. Active compound was isolated from mycelium extract of the fungus. The molecular formula of active compound was established as $\mathrm{C}_{27} \mathrm{H}_{21} \mathrm{~N}_{2} \mathrm{O}_{10} \mathrm{~S}_{2}$ by LC-ESI-ToF-MS m/z 597.1105 [M - H]. Elucidation of molecular structure using FT-IR, LC-ESI-ToF-MS, ${ }^{1} \mathrm{H}-\mathrm{NMR},{ }^{13} \mathrm{C}-\mathrm{NMR}$, and DEPT $135^{\circ}$ showed that the active compound was emestrin. Emestrin was found to have cytotoxic effect against T47D, $\mathrm{HepG}_{2}, \mathrm{C} 28$, and HeLa but it was not too toxic against Vero cells with $\mathrm{IC}_{50}$ value of $1.8 \mu \mathrm{g} \mathrm{mL}^{-1}, 4.2 \mu \mathrm{g} \mathrm{mL}^{-1}, 2.6 \mu \mathrm{g} \mathrm{mL}^{-1}, 13.8 \mu \mathrm{g} \mathrm{mL}^{-1}$, and $260.9 \mu \mathrm{g} \mathrm{mL}^{-1}$, respectively. Base on the cell cycle analysis by using flow cytometry, emestrin treatment at concentration of $1.0 \mu \mathrm{g} \mathrm{mL}^{-1}$ induced cell-cycle arrest in $\mathrm{G}_{0} / \mathrm{G}_{1}$ phase whereas at concentration of $3.0 \mu \mathrm{g} \mathrm{mL} \mathrm{m}^{-1}$, a sub-population of cells ( $\mathrm{sub}_{1}$ ) appeared. The apoptosis assay by using Annexin-V-FLUOS revealed that most of T47D cell treated with the compound at 1.0 and $3.0 \mu \mathrm{g} \mathrm{mL}^{-1}$ underwent apoptosis (83.6 and $92.6 \%$, respectively). This anticancer activity of emestrin may be related to the unique of the epithiodioxopiperazine moiety with internal disulphide bond of this compound.
\end{abstract}

Key words: apoptosis, cytotoxic, emestrin, Emericella nidulans

Penelitian untuk mengisolasi, mengidentifikasi, dan mengetahui aktivitas antikanker senyawa aktif yang dihasilkan oleh kapang laut Emericella nidulans sudah dilakukan. Senyawa aktif dari kapang E. nidulans berhasil diisolasi dari ekstrak miselium. Berdasarkan data spektra massa, senyawa aktif tersebut memiliki rumus molekul $\mathrm{C}_{27} \mathrm{H}_{21} \mathrm{~N}_{2} \mathrm{O}_{10} \mathrm{~S}_{2} \mathrm{~m} / \mathrm{z}$ $597.1105[\mathrm{M}-\mathrm{H}]$. Elusidasi struktur dengan menggunakan FT-IR, LC-ESI-ToF-MS, ${ }^{1} \mathrm{H}-\mathrm{NMR},{ }^{13} \mathrm{C}-\mathrm{NMR}$, dan DEPT- $135^{\circ}$ membuktikan bahwa senyawa aktif tersebut ialah emestrin. Emestrin memiliki aktivitas sitotoksik terhadap sel T47D, $\mathrm{HepG}_{2}$, $\mathrm{C} 28$, dan HeLa; tetapi tidak begitu toksik terhadap sel Vero dengan nilai $\mathrm{IC}_{50}$ berturut-turut sebesar $1.8 \mu \mathrm{g} \mathrm{mL}{ }^{-1}, 4.2 \mu \mathrm{gL}^{-1}$, $2.6 \mu \mathrm{g} \mathrm{mL}^{-1}, 13.8 \mu \mathrm{g} \mathrm{mL}^{-1}$, dan $260.9 \mu \mathrm{g} \mathrm{mL}^{-1}$. Berdasarkan analisis siklus sel terhadap sel T47D dengan menggunakan flow cytometry, perlakuan emestrin pada konsentrasi $1.0 \mu \mathrm{g} \mathrm{mL} \mathrm{m}^{-1}$ menyebabkan cell-cycle arrest pada fase $\mathrm{G}_{0} / \mathrm{G}_{1}$, sedangkan pada konsentrasi $3.0 \mu \mathrm{g} \mathrm{mL} \mathrm{m}^{-1}$ menyebabkan munculnya subpopulasi sel $\mathrm{G}_{1}$ pada kromatogram. Uji apoptosis dengan menggunakan Annexin-V-FLUOS memperlihatkan bahwa hampir sebagian besar sel T47D yang diberi perlakuan emestrin pada dosis 1.0 dan $3.0 \mu \mathrm{g} \mathrm{mL}^{-1}$ mengalami apoptosis (masing-masing sebesar 83.6 dan 92.6\%). Aktivitas antikanker emestrin kemungkinan besar disebabkan oleh adanya gugus epithiodioxopiperazine yang memiliki jembatan disulfida.

Kata kunci: apoptosis, Emericella nidulans, emestrin, sitotoksik

Marine microorganisms, particularly marine fungi, have recently drawn much attention as an important source of biologically active secondary metabolites. More recently, marine fungi have become an important research subject of natural products with significant value due to the diversity in chemical structures and biological activities (Gresa et al. 2009). About 70-80\% of the secondary metabolites that have been isolated from marine fungi are biologically active (Jadulco 2002; Gressa et al. 2009). Overall, research on marinederived fungi have led to the discovery of 272 new natural products including many that have novel

*Corresponding author, Phone :+62-21-53650158 Fax:+62-21-53650157,E-mail: muhammadnursid@gmail.com carbon skeletons; it is evident that marine-derived fungi have the potential to be a rich source of pharmaceutical leads compounds (Bugni and Ireland 2004).

Apoptosis or programmed cell death has, since its first description in 1972, become an important area of research due to the fact that it plays a pivotal role in embryonic development and in pathological processes. Apoptosis is also important in controlling cell number and proliferation as part of normal development. Apoptosis also occurs as a defense mechanism such as in immune reactions or when cells are damaged by disease or noxious agents (Ghobrial et al. 2005; Elmore 2007; Doonan and Cooter 2007). 
The killing of tumor cells by diverse cytotoxic approaches, such as anticancer drugs, gammairradiations or immunotherapy, is predominantly mediated through the induction of apoptosis. Apoptotic therapy has attracted many groups of investigator, and many companies had entered the race to develop the first generation of apoptotic anticancer medications. A number of anticancer agents, such as ciplastin, etoposide, mitomycin, and actinomysin $\mathrm{D}$ have been reported to induce apoptosis in cancer cells. Thus, apoptosis in cancer cells play a critical role in the killing of tumor cells during cancer chemotherapy (Genderen et al. 2003; Matsushita et al. 2005).

In the screening of bioactive secondary metabolites, we found that marine fungus strain MFW39 obtained from ascidian Aplidium longithorax collected from Wakatobi Marine National Park, South East Sulawesi, inhibited the growth of T47D (breast cancer) cell line. Molecular and morphological taxonomy of this fungus revealed that the fungus was a Emericella nidulans. Mycelium extract of this fungus had stronger cytotoxic activity $\left(\mathrm{IC}_{50}=21.9 \mu \mathrm{g} \mathrm{mL}^{-1}\right)$ than broth extract $\left(\mathrm{IC}_{50}=\right.$ $169.3 \mu \mathrm{g} \mathrm{mL}^{-1}$ ) (Nursid et al. 2011). The objective of this study was to isolate, identify, and investigate antitumor activity of active compound from mycelium produced by $E$. nidulans marine fungus.

\section{MATERIALS AND METHODS}

Fungal Material and Culture. E. nidulans MFW39 was isolated from the marine ascidia $A$. longithorax, which had been collected from the Wakatobi Marine National Park as previously described (Nursid et al. 2011). For production of secondary metabolites, the fungus was cultured $(1 \mathrm{~L} \mathrm{x}$ 20) for 5 weeks (static) at $27-29^{\circ} \mathrm{C}$ in SWS medium containing $0.1 \%$ soytone, $1.0 \%$ soluble starch, and seawater $100 \%$.

Isolation of Active Compound. The mycelium extract was fractionated by vacuum column on silica gel using n-hexane-EtOAc (8:1), n-hexane-EtOAc (1:1), EtOAc $100 \%$, and $\mathrm{MeOH} 100 \%$. Fraction 3 was separated in silica gel vacuum column using $n$-hexaneEtOAc (8:1), (5:1), (1:1), EtOAc 100\% and EtOAc$\mathrm{MeOH}$ (5:1). Fraction 3.3 and 3.4 was purified using silica gel preparative TLC.

TLC and HPLC Condition. Analytical TLC was performed by using silica gel aluminum plate $(3 \times 5$ $\mathrm{cm})$ whereas preparative TLC was performed by using silica gel glass plate $(10 \times 20 \mathrm{~cm})$ and developed with $n$-hexane EtOAc (1:1). Analytical HPLC was conducted using Shimadzu HPLC with Photodiode Array Detector 2996, column ODS 4.6 x $150 \mathrm{~mm}$
(Shimadzu), volume injection $20 \mu \mathrm{L}$, flow rate $1.0 \mathrm{~mL}$ $\min ^{-1}$, gradient (water $20 \%$ - acetonitrile $100 \%$ ), and time period was $45 \mathrm{~min}$.

Compound Identification. The active compound was identified by using spectroscopic analysis including infra-red (IR), mass spectra (MS), nuclear magnetic resonance (NMR, including ${ }^{1} \mathrm{H}-\mathrm{NMR},{ }^{13} \mathrm{C}$ NMR, and DEPT $135^{\circ}$ ). IR-spectra were recorded on Perkin Elmer One FT-IR spectrophotometer. Mass spectra were recorded using LC-ESI-ToF-MS (Waters, column SunFire $4.6 \times 150 \mathrm{~mm}$, isocratic water $+0.1 \%$ formic acid : acetonitrile $=45 / 55 \mathrm{v} / \mathrm{v}$, flow rate at 0.7 $\mathrm{mL} \min ^{-1}$, volume injection of $10 \mu \mathrm{L}$, capillary voltage $1800 \mathrm{~V}$, and cone voltage 60 volt). NMR spectra were recorded under conditions as indicated on a JEOL JNM ECA-500 spectrometer. Chemical shifts $(\delta)$ are given in parts per million downfield from TMS as internal standard.

Cytotoxicity Test. T47D (breast cancer), HepG2 (liver cancer), C28 (colon cancer), HeLa (cervix cancer), and Vero (normal cell) were cultured in RPMI 1640 medium (sigma), supplemented with $10 \%$ fetal bovine serum, $1 \%$ fungizone, and $2 \%$ penicillinstreptomycin. The cells were maintained at $37^{\circ} \mathrm{C}$ in a moisture-saturated atmosphere containing $5 \% \mathrm{CO}_{2}$. All of the cells were seeded at density of $2 \times 10^{4}$ cells well $^{-1}$ in $200 \mu \mathrm{L}$ of medium and allowed to attach overnight. After the cells were grown to about $80 \%$ confluence, treatment were initiated by supplementing to get $0.4,0.8,1.0,2.0,4.8,16.0,32.0$, and $64.0 \mu \mathrm{g} \mathrm{mL}^{-1}$ of final media concentration of compound. Cytotoxicity test was performed using 3-[4,5dimethylthiazol-2-yl]-2,5-diphenyl-tetrazolium bromide (MTT) assay according to Ebada et al. (2008). The MTT assay is a colorimetric assay base on the cleveage of yellow water-soluble tetrazolium salt, MTT, to form water-insoluble, dark blue formazan cristals. MTT cleveage occurs only in living cells by mitocondrial enzyme succinate dehydrogenase. The cleavage product formazan was measured spectrophotometrically at $570 \mathrm{~nm}$ using microplate reader (Dynex revelation). The percent inhibition of cells growth were calculated with formula:

$$
\text { (A-D) - (B-C)/(A-D) x } 100 \% \text {, }
$$

where A: control cell absorbance, B: compounds absorbance, C: controls compound absorbance, and D: control media absorbance. The inhibition concentration $50\left(\mathrm{IC}_{50}\right)$ value is defined as the concentrations of compound which inhibited $50 \%$ of the cell growth. $\mathrm{IC}_{50}$ value was determined by using Minitab probit analysis version 16.0.

Cell Cycle Analysis. The effects of the compounds on the cell cycle were studied by flow cytometry 
according to Rannali et al. (2003). Briefly, the T47D cell was seeded at a final density of $7 \times 100^{5}$ cells well $^{-1}$ in 6-well microculture and incubated for $12 \mathrm{~h}$ in $\mathrm{CO}_{2}$ incubator $\left(37^{\circ} \mathrm{C}, 5 \%\right.$ of $\mathrm{CO}_{2}$ flow). The compound was added to cells at 1.0 and $3.0 \mu \mathrm{g} \mathrm{mL}^{-1}$ for $24 \mathrm{~h}$. At the end of the incubation period, supernatant was collected and centrifuged at $200 \mathrm{~g} \mathrm{rpm}$ for $5 \mathrm{~min}$ to collect detach cells. The remaining cells were detached using $0.025 \%$ trypsin EDTA solution for approximately $5 \mathrm{~min}$. Pellet cells were washed with PBS twice then resuspended with $200 \mu \mathrm{g} \mathrm{ml}^{-1}$ of RNAse (Dnase free), $0.1 \%$ Triton $\mathrm{X}-100$ and $300 \mu \mathrm{L}$ propidium iodide (Roche). Mixtures were incubated at room temperature for $30 \mathrm{~min}$ and cell cycle distribution was analyzed using FACSCalibur (Becton-Dickinson) flow cytometer. Doxorubicin was used as a positive control.

Apoptosis Assay. Discrimination of apoptosis and necrosis cell was conducted using Annexin-V-FLUOS staining kit (Roche) according to Elmore (2007). After T47D cells treated with 1.0 and $3.0 \mu \mathrm{g} \mathrm{mL}^{-1}$ for $24 \mathrm{~h}$, the cells were trypsinized, washed with PBS, and resuspended the cell pellet in $100 \mu \mathrm{L}$ of Annexin-VFLUOS staining kit. The cells then incubated in dark room for $10 \mathrm{~min}$ at $20-25{ }^{\circ} \mathrm{C}$. Typical histogram of apoptotic and necrotic cells was performed using FACSCalibur (Becton-Dickinson) flow cytometer. Doxorubicin was used as a positive control.

\section{RESULTS}

Isolation and Identification of Active Compound. The resulting broth and mycelium were separately extracted with EtOAc and $\mathrm{CH}_{2} \mathrm{Cl}_{2}-\mathrm{MeOH}$ (1:1) to obtain crude extracts of 0.46 and $37.0 \mathrm{~g}$, respectively. Based on MTT test, the mycelium extract showed stronger cytotoxic activity than broth extract against T47D cell. The active components

on mycelium extract were purified using assay-guided isolation to yield the active compound. The active compound appeared as yellow solid and display a single spot on TLC [ $n$-hexane:EtOAc $(1: 1 \mathrm{v} / \mathrm{v})(R f$ value of 0.45)] (Fig 1). The active compound was eluted at $15 \mathrm{~min}$ in the HPLC chromatogram (Fig 2).

The molecular formula of active compound was established as $\mathrm{C}_{27} \mathrm{H}_{21} \mathrm{~N}_{2} \mathrm{O}_{10} \mathrm{~S}_{2}$ by LC-ESI-ToF-MS (m/z 597.1105 [M - H] (Fig 3). IR absorption at $3447 \mathrm{~cm}^{-1}$, $1688 \mathrm{~cm}^{-1}$ and $1614 \mathrm{~cm}^{-1}$ indicated the presence of hydroxyl, ester and amide groups. The ${ }^{1} \mathrm{H}-\mathrm{NMR}$ and ${ }^{13} \mathrm{C}$-NMR (Fig 4) of active compound in $\mathrm{CDCl}_{3}$ showed methoxy group $\left(\delta_{\mathrm{H}} 4.0\right.$ and $\left.\delta_{\mathrm{C}} 56.5\right), N$-methyl group $\left(\delta_{\mathrm{H}} 3.4\right.$ and $\left.\delta_{\mathrm{C}} 28.0\right)$, and two hydroxyl groups $\left(\delta_{\mathrm{H}} 5.5\right.$ and $\left.\delta_{\mathrm{C}} 6.3\right)$. The ${ }^{13} \mathrm{C}$-NMR spectrum of active compound displayed 27 carbon signals consisting of 2 methyl $\left(\mathrm{Ch}_{3}\right), 13$ methine $(\mathrm{CH})$, and 12 quaternary carbons as judged by DEPT $135^{\circ}$ spectrum (Fig 5). These spectra were closely similar to the spectrum of emestrin (Fig 6) that reported previously by Seya et al. (1985); Ooike et al. (1997); Onodera et al. (2004); and

A

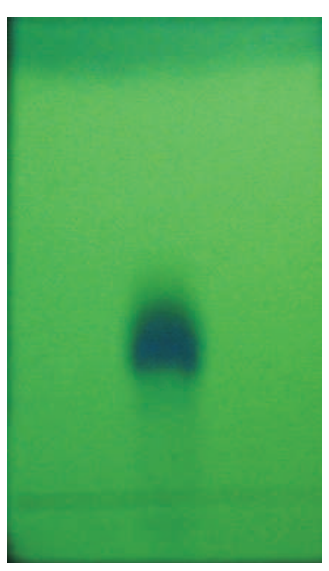

Fig 1 TLC of E. nidulans active compound under $254 \mathrm{~nm} \mathrm{UV} \mathrm{(A)} \mathrm{and}$ sprayed with phosphomolybdic acid(B).

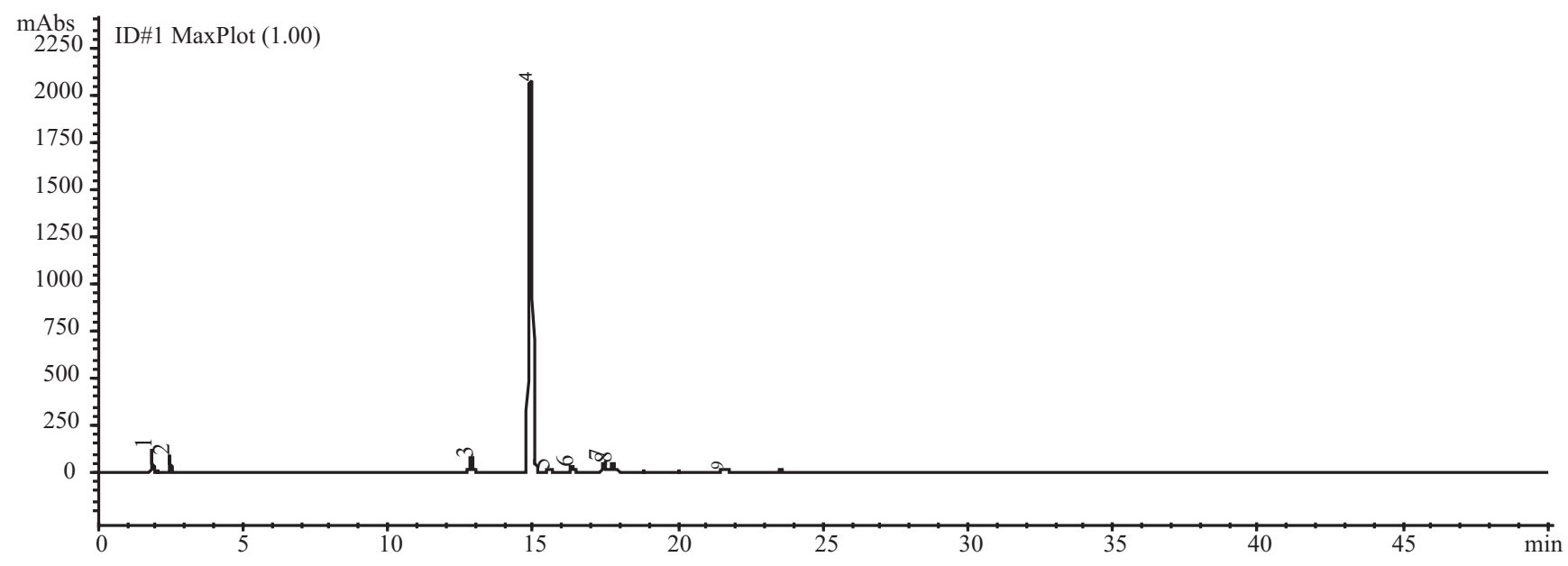




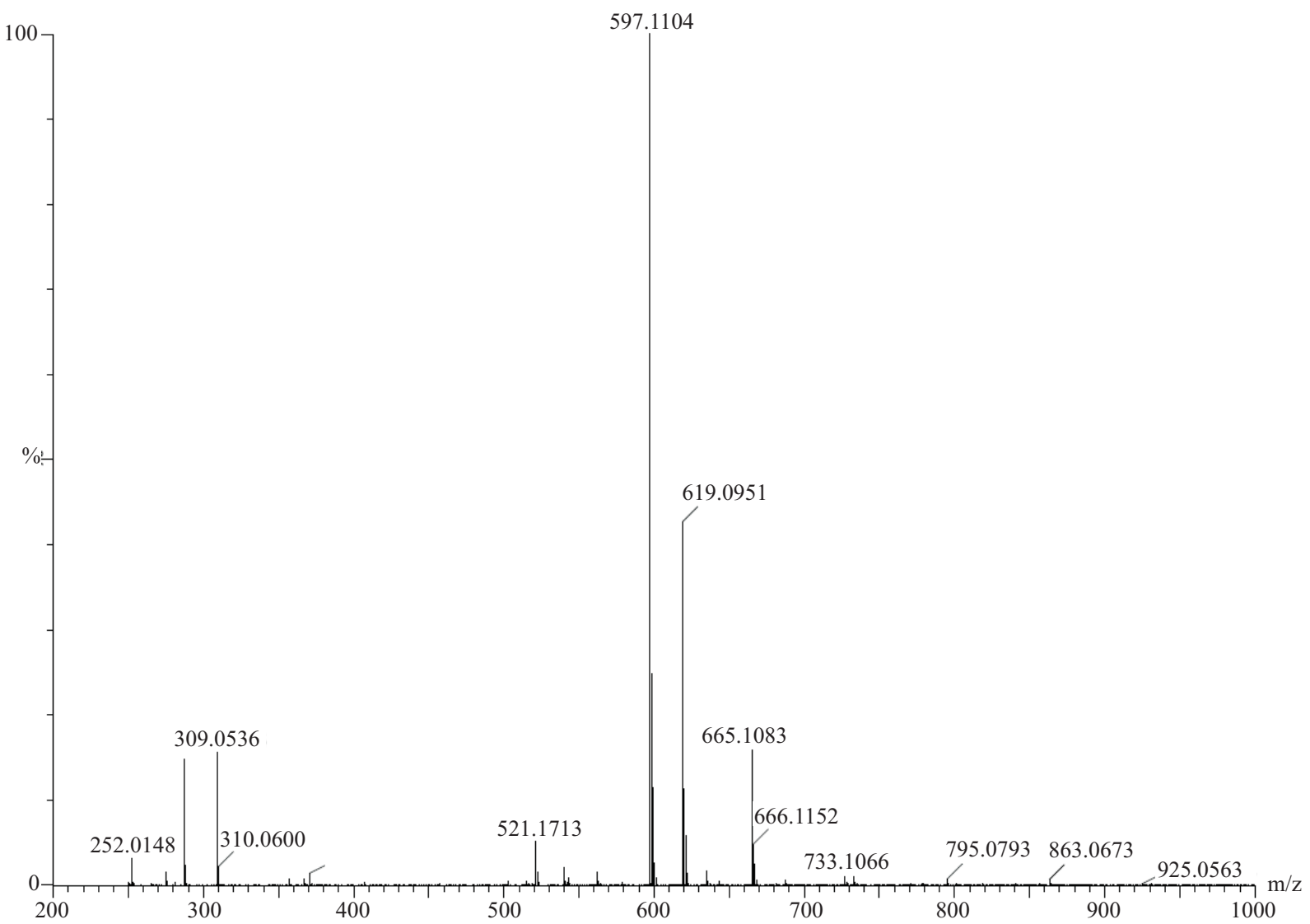

Fig 3 LC-ESI-ToF-MS spectrum of E. nidulans active compound.

Herath et al. (2005). The summary of ${ }^{1} \mathrm{H}-\mathrm{NMR},{ }^{13} \mathrm{C}$ NMR and reported emestrin was showed in Table 1.

Cytotoxic Activity. The MTT test used for the evaluation of cytotoxic properties of the active compound in this research. The growth-inhibitory effects were studied in five cell lines, including T47D (breast cancer), HepG2 (liver cancer), C28 (colon cancer), HeLa (cervix cancer) and Vero (normal cell). Morphological changes in the cells caused by emestrin were observed by microscope as shown in Fig 7. After $24 \mathrm{~h}$ incubation with the compound at concentration $0.8,2.0$, and $16.0 \mu \mathrm{g} \mathrm{mL} \mathrm{m}^{-1}$, morphology of T47D, HepG2 and C28 cells changed, but the morphology of HeLa cells changed only after emestrin treatment at $16.0 \mu \mathrm{g} \mathrm{mL}^{-1}$. In contrast, there were no morphological changes in Vero and untreated cells (control).

Growth inhibition of T47D, HepG2, C28 HeLa, and Vero cells after treated with emestrin were shown in Fig 8. Emestrin tested showed a dose-dependent inhibition of all cells except to Vero cell. Probit analysis showed that emestrin had strong cytotoxicity activity to T47D, HepG2, C28, and HeLa cells but it was not too toxic to Vero cell (Table 2). In further study we used T47D cells because it was highest inhibited by emestrin.
Effects on Cell Cycle Arrest in T47D Cells. Cell cycle distribution of T47d cells exposed to emestrin was investigated by flow cytometry. T47D cells were exposed to the emestrin at 1.0 and $3.0 \mu \mathrm{g} \mathrm{mL}^{-1}$ for $24 \mathrm{~h}$, and the fraction of cells at different phases of the cell cycle were monitored after propidium iodide (PI) staining. Following the emestrin treatment at concentration $3.0 \mu \mathrm{g} \mathrm{mL}^{-1}$, an apoptotic sub-population of cells ( $\left(\mathrm{sub}_{1}\right.$ ) appears (Fig 9). On the contrary, there were no sub $G_{1}$ in the cell controls. In Fig 9, also it can be seen that emestrin treatment at concentration of $1.0 \mu \mathrm{g} \mathrm{mL} \mathrm{m}^{-1}$ induced cell-cycle arrest in $\mathrm{G}_{0} / \mathrm{G}_{1}$ phase.

Induced Apoptosis in T47D Cells. Next the cells were exposed to $1.0 \mu \mathrm{g} \mathrm{mL}^{-1}$ and $3.0 \mu \mathrm{g} \mathrm{mL}^{-1}$ of emestrin for $24 \mathrm{~h}$ and the cells were stained with annexin-PI to discriminate apoptosis, necrosis and viable cells. Almost T47D cells were treated with emestrin underwent apoptosis. Percentage of apoptotic cells were $83.6 \%$ at $1.0 \mu \mathrm{g} \mathrm{mL} \mathrm{m}^{-1}$ of emestrin concentration and increased at concentration $3.0 \mu \mathrm{g}$ $\mathrm{mL}^{-1}(92.6 \%)$. Only $6.4 \%$ and $2.9 \%$ of dead cells were caused by necrosis at concentration $1.0 \mu \mathrm{g} \mathrm{mL}^{-1}$ and 3.0 $\mu \mathrm{g} / \mathrm{ml}$ of emestrin, respectively (Fig 10). 

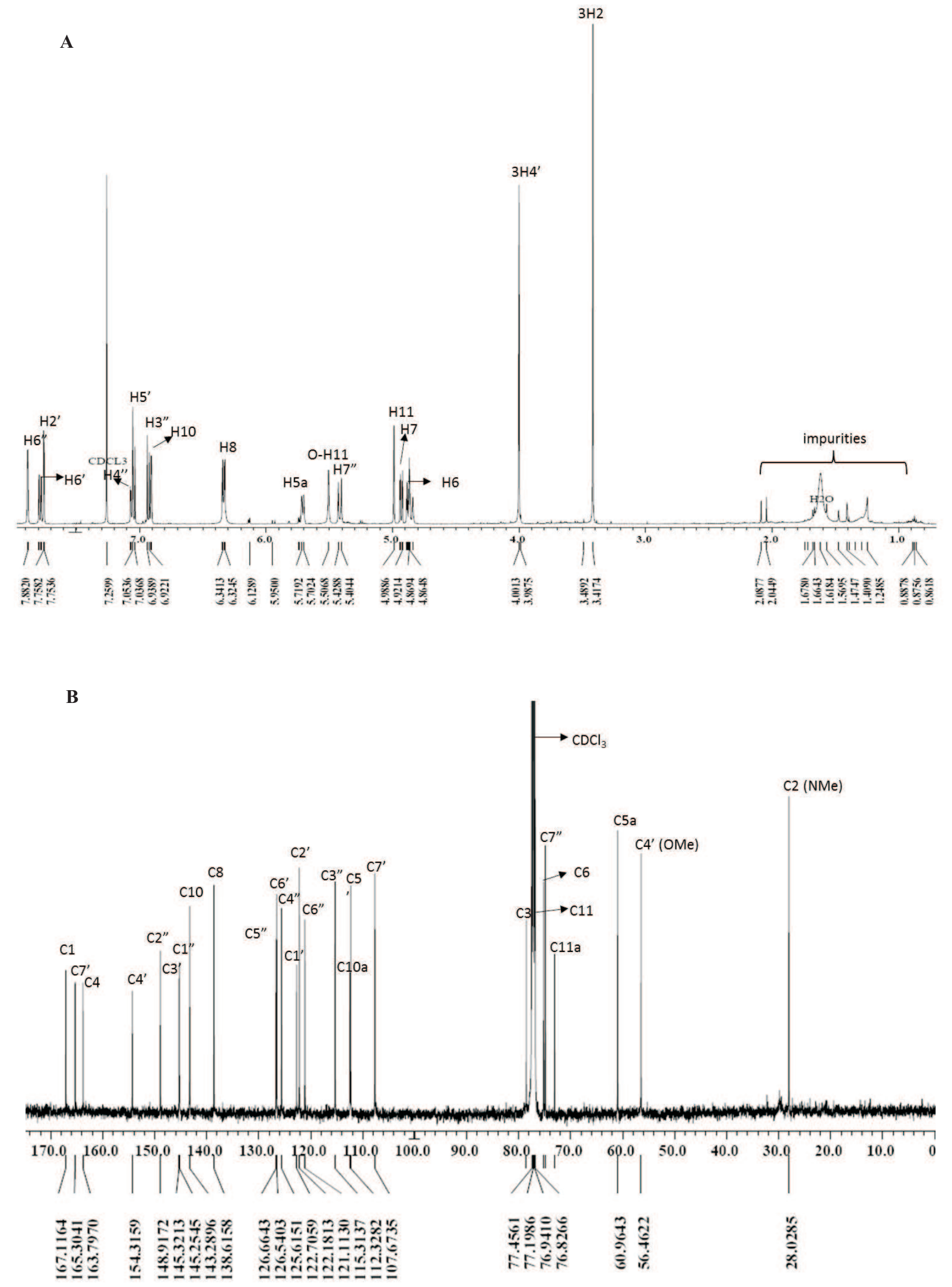

Fig $4{ }^{1} \mathrm{H}-\mathrm{NMR}$ (A) and ${ }^{13} \mathrm{C}-\mathrm{NMR}$ (B) spectrum of E. nidulans active compound. 

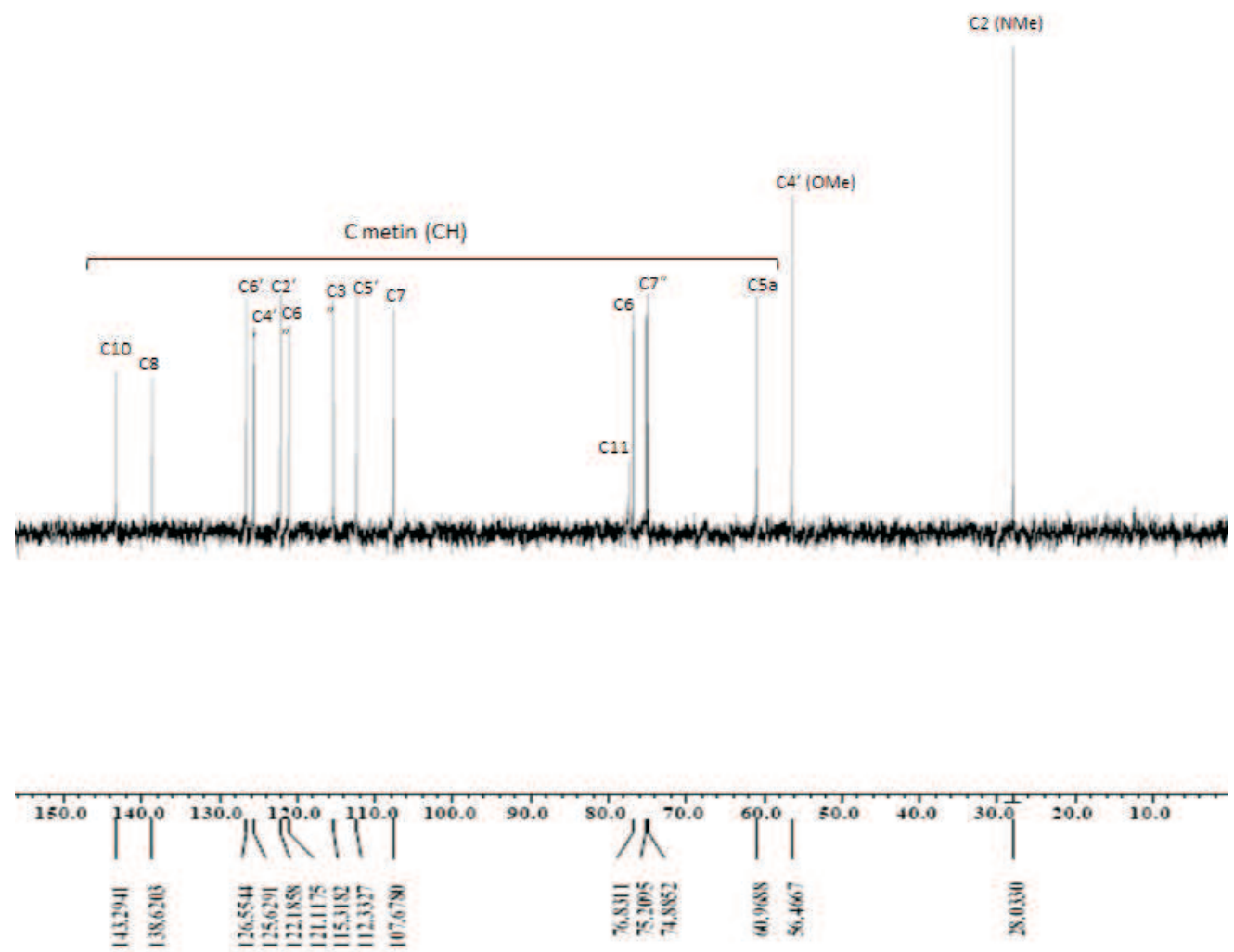

Fig 5 DEPT $135^{\circ}$ spectrum of E. nidulans active compound

Table $1{ }^{1} \mathrm{H}$-NMR and ${ }^{13} \mathrm{C}$-NMR of $E$. nidulans active compound compare with emestrin

\begin{tabular}{|c|c|c|c|c|}
\hline \multirow{2}{*}{ Carbon Number } & \multicolumn{2}{|l|}{ Active Compound } & \multicolumn{2}{|c|}{ Emestrin } \\
\hline & dH ( $\Sigma$ H, Multiciplity, $J$ coupling) & $\delta \mathrm{C}$ & $\delta \mathbf{H}$ & $\delta \mathrm{C}$ \\
\hline 1 & & 167.1 & & 168.0 \\
\hline 2-NMe & $3.40(3 \mathrm{H}, \mathrm{s})$ & 28 & 3.43 & 28.8 \\
\hline 3 & & 78.5 & & 77.9 \\
\hline 4 & & 163.8 & & 165.2 \\
\hline $5 \mathrm{a}$ & $5.71(1 \mathrm{H}, \mathrm{d}, 8.4 \mathrm{~Hz})$ & 60.9 & 5.93 & 58.9 \\
\hline 6 & $4.88(1 \mathrm{H}, \mathrm{td}, 2.3 \& 2.8 \mathrm{~Hz})$ & 75.2 & 4.82 & 74.8 \\
\hline 7 & $4.93(1 \mathrm{H}, \mathrm{dd}, 2.3 \& 8.4 \mathrm{~Hz})$ & 107.7 & 4.98 & 109.9 \\
\hline 8 & $6.32(1 \mathrm{H}, \mathrm{dd}, 2.3 \& 8.4 \mathrm{~Hz})$ & 138.6 & 6.34 & 138.5 \\
\hline 10 & $6.91(1 \mathrm{H}, \mathrm{d}, 2.3 \mathrm{~Hz})$ & 143.3 & 6.91 & 142.9 \\
\hline $10 \mathrm{a}$ & & 112.5 & & 107.8 \\
\hline 11 & $4.98(1 \mathrm{H}, \mathrm{s})$ & 76.8 & 4.98 & 79.7 \\
\hline $11-\mathrm{OH}$ & $5.5(\mathrm{~s}, 1 \mathrm{H})$ & & 5.23 & \\
\hline $11 \mathrm{a}$ & & 73.1 & & 83.0 \\
\hline $1^{\prime}$ & & 122.7 & & 119.4 \\
\hline $2^{\prime}$ & $7.75(1 \mathrm{H}, \mathrm{d}, 2.3 \mathrm{~Hz})$ & 122.2 & 7.66 & 122.2 \\
\hline $3^{\prime}$ & & 145.3 & & 146.2 \\
\hline 4, & & 154.3 & & 154.6 \\
\hline 4'-OMe & $4.0(3 \mathrm{H}, \mathrm{s})$ & 56.5 & 4.02 & 56.3 \\
\hline $5^{\prime}$ & $7.04(1 \mathrm{H}, \mathrm{d}, 8.4 \mathrm{~Hz})$ & 112.3 & 7.06 & 112.1 \\
\hline $6^{\prime}$ & $7.79(1 \mathrm{H}, \mathrm{dd}, 1.55 \mathrm{~Hz})$ & 126.5 & 7.78 & 125.8 \\
\hline $7^{\prime}$ & & 165.3 & & 166.3 \\
\hline $1 "$ & & 145.2 & & 145.5 \\
\hline $2^{\prime \prime}$ & & 148.9 & & 152.1 \\
\hline 2"-OH & $6.32(1 \mathrm{H})$ & & 4.77 & \\
\hline $3 "$ & $6.92(1 \mathrm{H}, \mathrm{d}, 8.4 \mathrm{~Hz})$ & 115.3 & 6.95 & 110.6 \\
\hline $4 "$ & $7.07(1 \mathrm{H}, \mathrm{d}, 2.3 \mathrm{~Hz})$ & 125.6 & 7.13 & 125.5 \\
\hline $5^{\prime \prime}$ & & 126.7 & & 128.6 \\
\hline $6 "$ & $7.88(1 \mathrm{H}, \mathrm{d}, 2.3 \mathrm{~Hz})$ & 121.1 & 7.68 & 126.9 \\
\hline 7" & $5.41(1 \mathrm{H}, \mathrm{d}, 12.2 \mathrm{~Hz})$ & 74.9 & 5.45 & 76.4 \\
\hline
\end{tabular}

Note $: \mathrm{s}=$ singlet, $\mathrm{d}=$ doblet, $\mathrm{dd}=$ doblet-doblet, $\mathrm{td}=$ triple-doblet 


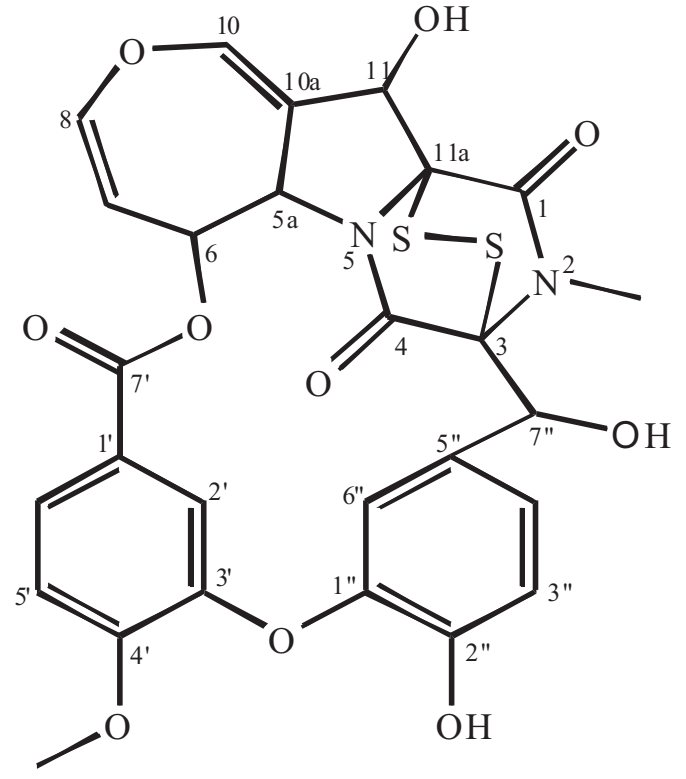

Fig 6 Molecular structure of emestrin.

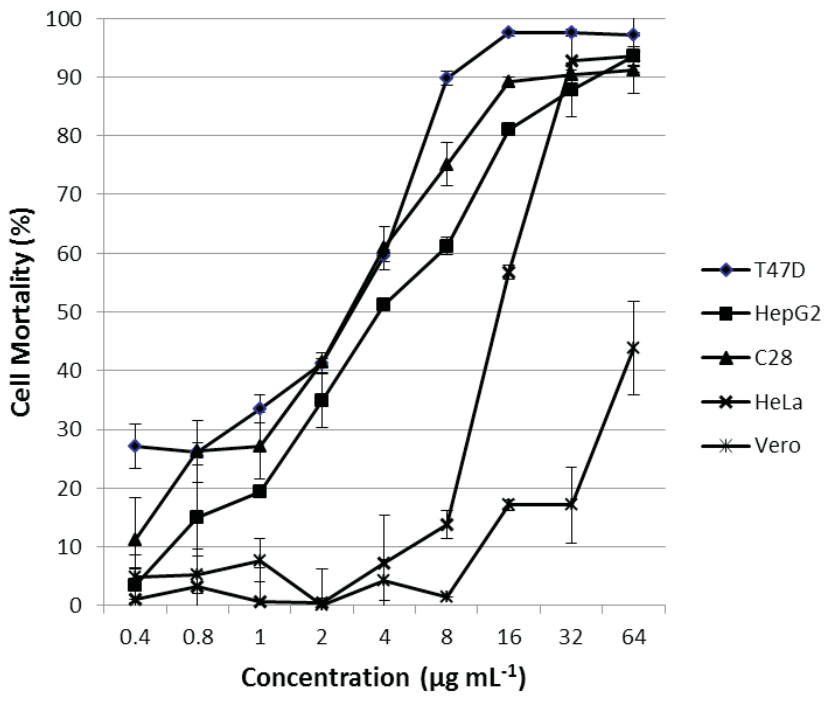

Fig 8 Growth inhibition of T47D, HepG2, C28, HeLa, and Vero cells after treated with various concentration of emestrin for $24 \mathrm{~h}( \pm$ standard deviations).

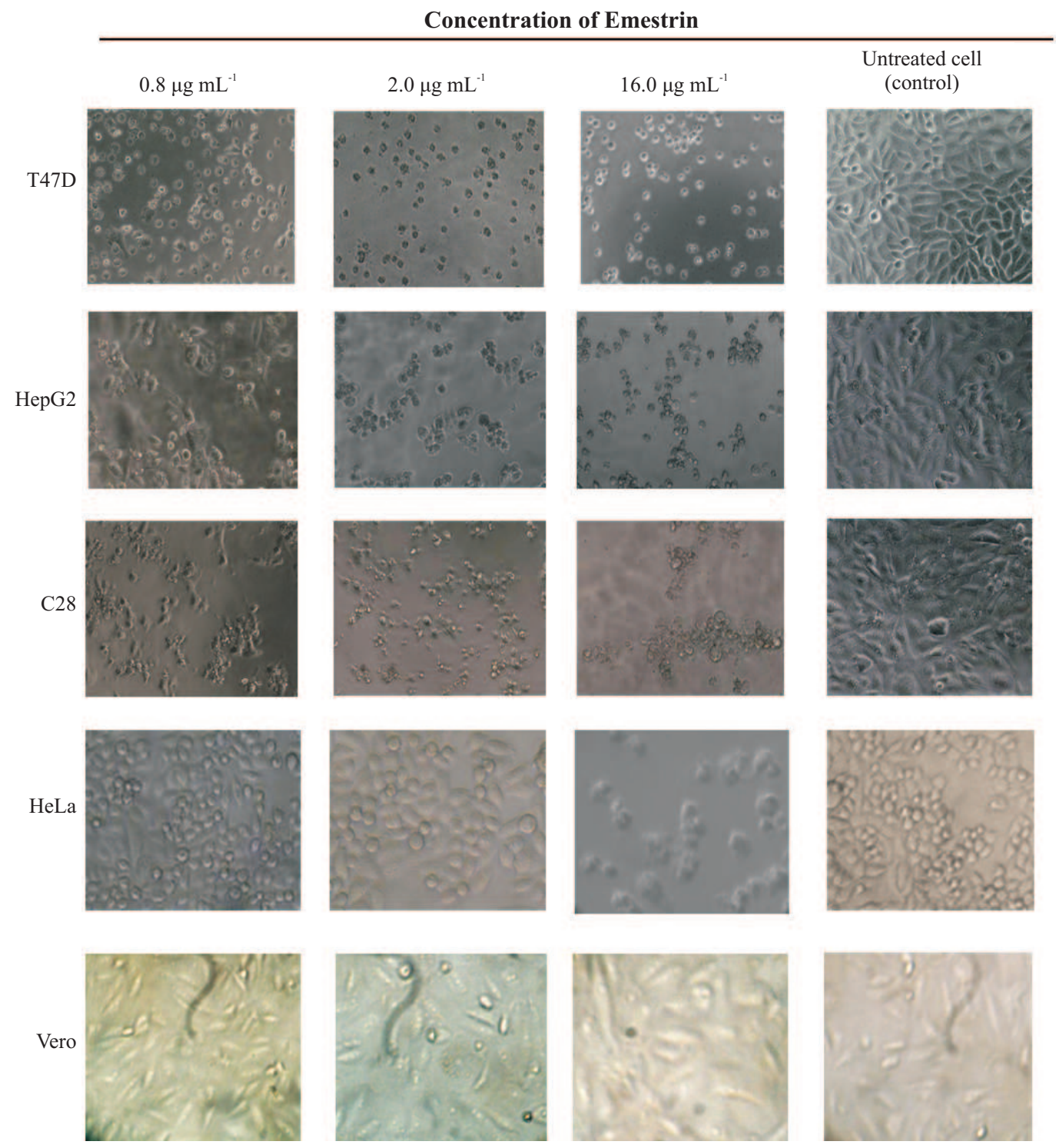

Fig 7 Morphological changes in T47D, HepG2, C28 HeLa, and Vero cells after treated with emestrin (magnification $100 \mathrm{x}$ under inverted microscope). 
Table $2 \mathrm{IC}_{50}$ values of emestrin against several types of cells

\begin{tabular}{lc}
\hline Cancer cell lines & $\mathrm{IC}_{50}\left(\mu \mathrm{g} \mathrm{mL}^{-1}\right)$ \\
\hline T47D (breast cancer) & $1.8 \pm 0.1$ \\
HepG2 (liver cancer) & $4.2 \pm 0.6$ \\
C28 (colon cancer) & $2.6 \pm 0.3$ \\
HeLa (cervix cancer) & $13.8 \pm 1.5$ \\
Vero (normal cell) & $260.9 \pm 49.9$ \\
\hline
\end{tabular}
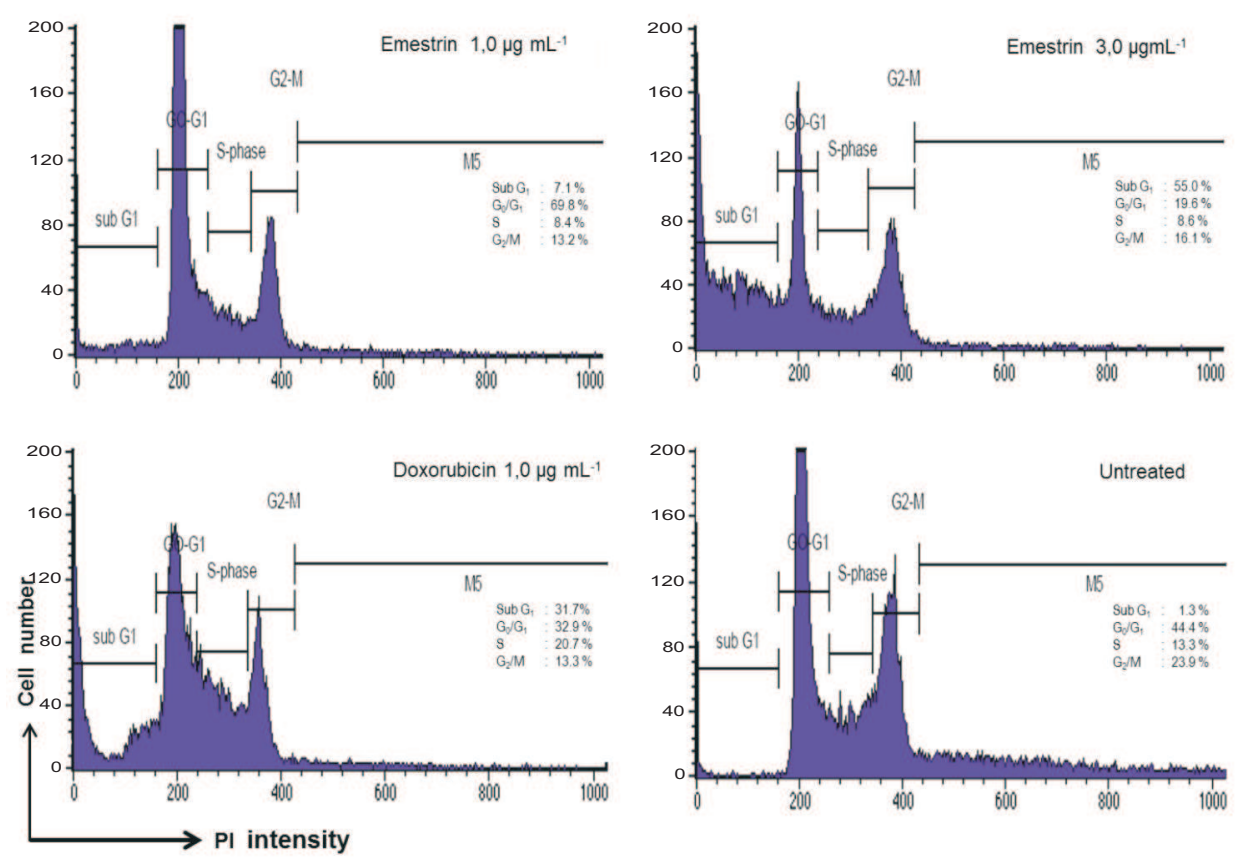

Fig 9 Flow cytometric analysis of the DNA histogram of PI-stained T47D cells.
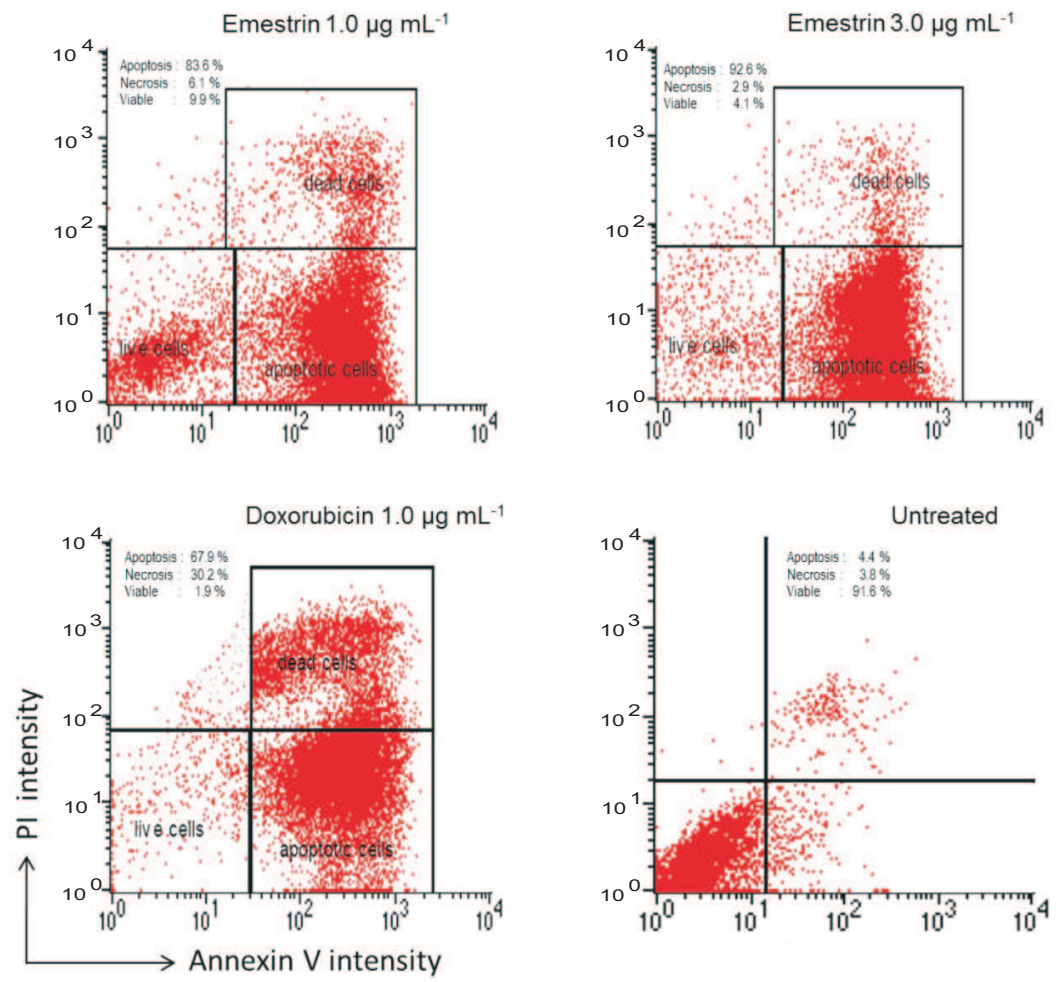

Fig 10 Apoptosis and necrosis were induced in T47D cells detected by annexin-PI staining and compared to the cells control. Viable cells: lower left quadrant; apoptotic cells: lower right quadrant; and necrotic cells: upper right quadrant. 


\section{DISCUSSION}

Emestrin was isolated by Seya et al. in 1985 from mycelial acetone extracts of the fungus Emericella striata. Emestrin is a member of a group epithiodioxopiperazine (ETP) that are toxic secondary metabolites made only by fungi. At least 14 different ETPs (excluding those with minor modifications) are known. The diversity of structures stems from the amino acids of the core ETP moiety, as well as the modifications of these amino acids. All natural ETP isolated to date contain at least one aromatic amino acid. A diverse range of filamentous ascomycetes produce ETP. Five classes of ascomycetes (Dothideomycetes, Eurotiomycetes, Lecanoromycetes, Saccharomycetes and Sordariomycetes) are known produce ETP. At least two basidiomycetes, Stereum hirsutum and a Hyalodendron sp., produce ETP epicorazine and hyalodendrin, respectively (Gardiner etal.2005).

Several natural products containing ETP moieties have so far been reported to be promising as a antitumor agent such us MPC 1001 (emestrin C), gliotoxin and chaetoxin. Emestrin $\mathrm{C}$ showed antiproliferative activities against DU145 human prostate cancer cell line with $\mathrm{IC}_{50}$ value of $9.3 \mathrm{nM}$. The toxicity of ETPs is due to the presence of a disulphide bridge, that can inactivate proteins via reaction with thiol groups, and to the generation of reactive oxygen species by redox cycling (Onodera et al. 2004; Gardiner et al. 2005).

We have demonstrated that emestrin strongly inhibits the growth of T47D, HepG2 and C28 cells. This compound had $\mathrm{IC}_{50}$ values of $<5 \mu \mathrm{g} \mathrm{mL}^{-1}$ to these cells. Microscopic study (Fig 9) exhibited that cells morphology changed from taper to round or irregular shape. Under microscopy analysis, many cell populations detached from microplate after exposed to the compound for $24 \mathrm{~h}$. The cytotoxicity of emestrin to these cells related to the structure of ETP moiety. When T47D cells were treated with the emestrin, ETP moiety may interact with the cell membrane to alter permeability characteristics and then affect the entry or exit of amino acids and nucleotides known to regulate cellular metabolism, and thus result in cellular structural changes simultaneously with their functional changes in both physiological and pathological conditions. This effect implies that ETP moietyinduced disruption could functionally and structurally damage cell membrane as well as other cellular structures and ultimately cause cell death.

The formation of distinct DNA fragments is a biochemical hallmark of apoptosis, with internucleosomal DNA cleavage activity as a major characteristic (Rannali et al. 2003; Yu et al. 2005). The normal metabolic cellular activities of the $\mathrm{G}_{1}$ period in cell division are in preparation for mitosis, including transcription translation, and increase of cytoplasmic materials. The flow cytometry study presented in this report suggests a possible association between emestrin and cell cycle arrest activity. As shown in Fig 9, the emestrin apparently affected the proliferation of T47D cells by inhibited the progression of the T47D cells through the $\mathrm{G}_{1}$ phase of the cell cycle. When T47D cells were treated with emestrin, apoptotic cells with high DNA content apparently accumulate during the G1 period, in comparison with the untreated cells (Fig 9). As a result, the synthesis of proteins involved in transcriptional regulation and cell cycle control and the completion of the $\mathrm{S}$ and $\mathrm{M}$ phases are delayed, giving rise to a plethora of cellular effects, not least of which is potential activation of pathways leading to cell cycle arrest and apoptosis (Yu et al. 2005).

When a cell undergoes apoptosis, changes occur at the cell surface. One of plasma membrane alteration is the translocation of phosphatidylserine (PS) from the inner part of the plasma membrane to the out layer, by which PS becomes exposed at the external surface of the cells. PS exposure therefore represent a useful assay for the apoptosis. PS present on the outer leaflet can be detected using Annexin V (Elmore 2007). Annexin V is $\mathrm{Ca}^{2+}$-dependent phospholipid-binding protein with high affinity for PS. This protein can hence be used as a sensitive probe for PS exposure upon the outer leaflet of the cell membrane and is, therefore, suited to detect apoptosis cells. Necrotic cells also expose PS, and will therefore also bind Annexin V. To differentiate between apoptotic and necrotic cells, PI is often used in conjunction with Annexin V. PI will mark necrotic cells, but not apoptotic cells. In this assay, Annexin V bind the phospholipid PS, marking apoptotic and necrotic cells, while PI bind DNA, marking only necrotic cells (Ranalli etal.2003).

In this research, we assayed the ability of emestrin to induce apoptosis in cells. The double staining of annexin V-propidium iodide by Annexin-V-FLUOS Staining Kit analysis showed that emestrin was a potent inducer of apoptosis in T47D cells. Fig 10 showed that emestrin at 1.0 and $3.05 .0 \mu \mathrm{g} \mathrm{mL}^{-1}$ could induce the high amount of apoptosis in T47D cells. It were higher than doxorubicin at $5.0 \mu \mathrm{g} \mathrm{mL}^{-1}$. Doxorubicin (14hidroxydaunorubicin) is an antracyclic antibiotic drug widely used in the treatment of a variety of cancers. Doxorubicin has multiple mechanisms of action, including its interaction with the enzyme topoisomerase II, metal ion chelation and free radical generation. 
More recently doxorubicin was found to reduce the viability of cancer cells via RNA damage (Brilhante et al.2011).

Base on the cytotoxicity test, cell cycle analysis and apoptosis assay, we can infer that the emestrin was potential as anticancer agent. This anticancer activity may be related to the unique of the internal disulphide bond of emestrin, although this hypothesis could be further proved.

\section{ACKNOWLEDGMENT}

This research was supported by Ministry of Marine and Fisheries Affairs. We thanks to Farid Abdullah and Juana Nursanthi (Pathology Clinic Lab and Parasitology Lab., Faculty of Medicine, Universitas Gadjah Mada, Yogyakarta) for the flow cytometry analysis, Anis Mahsunah $\left(\mathrm{P}_{3}\right.$ Biotechnology BPPT) for the LC-ESI-ToF-MS, Sofa Fajriyah and Akhmad Darmawan (Puslit Kimia LIPI) for the NMR data, and Asri Pratitis (Biotechnology Lab., Research Center for Marine and Fisheries Product Processing and Biotechnology, Jakarta) for the fungus isolation.

\section{REFERENCES}

Bugni TS, Ireland CM. 2004. Marine-derived fungi: a chemically and biologically diverse group of microorganisms. Nat Prod Rep. 21:143163. doi: 10.1039/b301926h.

Brilhante O, Stumpp T, Miraglia SM. 2011. Long-term testicular toxicity caused by doxorubicin treatment during pre-pubertal phase. Int J Med Med Sci. 3(2):52-60.

Ebada SE, Edrada RU, Lin W, Proksch P. 2008. Methods for isolation, purification and structural elucidation of bioactive secondary metabolites from marine invertebrates. Nat Prot. 3(12):1820-1831. doi: $10.1038 /$ nprot.2008.182.

Elmore S. 2007. Apoptosis: a review of programmed cell death. Toxicol Pathol. 35(4):495-516. doi: 10.1080/01926230701320337.

Doonan F, Cotter TG. 2008. Morphological assessment of apoptosis. Methods 44:200-204. doi:10.1016/j.ymeth.2007.11.006.

Gardiner DM, Waring P, Howlett BJ. 2005. The epipolythiodioxopiperazine (ETP) class of fungal toxins: distribution, mode of action, functions and biosynthesis. Microbiology 151(4):1021-1032. doi: 10.1099/mic. 0.27847-0.
Ghobrial IM, Witzig TE Adjei AA. 2005. Targeting apoptosis pathways in cancer therapy. CA Cancer J Clin. 55:178-194. doi: 10.3322/canjclin.55.3.178

Gresa MPL, Cabedo N, Mas MCG, Ciavatta ML, Avila C, Primo J. 2009. Terretonins $\mathrm{E}$ and $\mathrm{F}$, inhibitors of the mitochondrial respiratory chain from the marine-derived fungus Aspergillus insuetus. J Nat Prod. 72(7):1348-351. doi: 0.1021/np900085n.

Ranalli M, Oberst A, Corazzari M, Laurenzi VD. Flow cytometric studies of cell death. 2003. In: Hughes D, Mehmet H, editors. Cell Proliferation and Apoptosis. Oxford (US): BIOS Scientific Publisher Limited. p 330-359.

Genderen HV, Kenis H, Dumont E, Heerde WV, Hofstra L, Reutelingsperger CP. 2003. Membrane alteration in dying cells. In: Hughes D, Mehmet H, editors. Cell Proliferation and Apoptosis. Oxford (US): BIOS Scientific Publisher Limited. p 185-186.

Herath KB, Jayasuriya H, Ondeyka JG, Polishook JD, Bills GF, Dombrowski AW, Cabello A, Vicario PP, Zweerink H, Guan Z, Singh S.B. 2005. Isolation and structures of novel fungal metabolites as chemokine receptor (CCR2) antagonists. J Antibiot. 58 (11):686-694.

Jadulco RC. 2002. Isolation and structure elucidation of bioactive secondary metabolites from marine sponge and sponge derived-fungi. [dissertation]. Wuzburg (DE): Universitat Wurzburg.

Matsushita H, Kuwabara H, Ishikawa S, Mochizuki M. 2005. Apoptosis induced in human cells lines by a butanol extract from Chlorophytum comosum roots. J Health Sci. 51(3):341-345.

Nursid M, Chasanah E, Murwantoko, Wahyuono, S. 2011. Penapisan kapang laut penghasil senyawa sitotoksik dari beberapa wilayah perairan Indonesia [Screening of marine fungi producing cytotoxic compound from Indonesia waters]. JPB Kelautan dan Perikanan $6(1): 45-56$.

Ooike M, Nozawa K, Kawai K. 1997. An epitetrathiodiopiperazine related to emestrin from Emericella foveolata. Phytochemistry 46 (1):123126 .

Onodera H, Hasegawa A, Tsumagari N, Nakai R, Ogawa T, Kanda, Y. 2004. MPC1001 and its analogues: new antitumor agents from the fungus Cladorrhinum species. Org Lett. 6(22): 4101-4104. doi: 10.1021/o1048202d.

Ranalli M, Oberst A, Corazzari M, Laurenzi VD. Flow cytometric studies of cell death. 2003. In: Hughes D, Mehmet, H, editors. Cell Proliferation and Apoptosis. Oxford (US): BIOS Scientific Publisher Limited. 338-340.

Saraste A, Pulkki K. 2000. Morphologic and biochemical hallmarks of apoptosis. Cardiovasc Res. 45:528-537.

Seya K, Nakajima S, Kawai K. 1985. Structure and absolute configuration of emestrin, a new macrocyclic epidithiodioxopiperazine from Emericella striata. J Chem Soc Chem Com. 117:657-658.

Yu FR, Lian XZ, Guo HY, McGuire PM, Li RD, Wang R, Yu FH. 2005. Isolation and characterization of methyl esters and derivatives from Euphorbia kansui (Euphorbiaceae) and their inhibitory effects on the human SGC-7901 cells. J Pharm Pharmaceut Sci. 8(3):528-535. 